\title{
DAMPAK KEPATUHAN WAJIB PAJAK UMKM DALAM MENINGKATKAN PENERIMAAN PAJAK PADA KPP PRATAMA SEKAYU KABUPATEN MUSI BANYUASIN
}

\author{
Farida Aryani \\ STIE Rahmaniyah Sekayu \\ email: farida021070@gmail.com
}

\begin{abstract}
This research is a descriptive research with quantitative analysis technique using the calculation and graphic illustration to analyze the effects of tax payers compliance in increasing the revenue of UMKN tax at KPP Pratama Sekayu. The purpose of this research is to know the effects of the tax payers compliance in increasing the revenue of UMKM tax at KPP Pratama Sekayu. Data which is analyzed is the data of UMKM tax payers which is registered and paid the tax as well as the target and realization the revenue of UMKM tax. The result of this research shows that the level of tax payers compliance is in the average $63.92 \%$. The UMKM tax payers compliance in paying the tax can not increase the amount of UMKM tax reception due to the fact that the amount of tax payers increases every year, but the realization amount of tax revenue decreases. This thing happens due to the fact that the tax payers who have the compliance to pay the tax are the tax payers who have relatively small revenue. So, in spite of the fact that the amount the tax payers is big, however the effects for the tax revenue realization is still small due to the fact that the amount of the tax paid is small.
\end{abstract}

Keywords: Tax Payers Compliance, UMKM Tax Payers, Tax Revenue.

\section{PENDAHULUAN}

\subsection{Latar Belakang Masalah}

Pajak sebagai salah satu target utama pemerintah yang dijadikan sumber pendapatan negara dalam membiayai pengeluaran rutin pemerintah serta pembangunan. Pajak dalam pendapatan negara tergolong paling besar dibanding sektor lain, dimana 70\% dari Anggaran Pendapatan dan Belanja Negara bersumber dai pajak. Salah satu sumber penerimaan pajak yang sangat potensial adalah UMKM.

Usaha Mikro Kecil Menegah (UMKM) adalah salah satu pelaku ekonomi yang berperan penting dalam menggerakkan dan mendukung pertumbuhan ekonomi Indonesia. UMKM sebagai pelaku ekonomi produktif merupakan sumber penerimaan pajak yang potensial dan menjanjikan bagi pemerintah. Pemerintah selalu berupaya untuk meningkatkan penerimaan pajak dari sektor UMKM dengan menetapkan berbagai kebijakan baik dari kemudahan administrasi maupun dengan penurunan tarif pajak. Salah satu kebijakan yang dikeluarkan pemerintah yaitu 
Peraturan Pemerintah No. 23 Tahun 2018 tentang pajak penghasilan atas penghasilan dari usaha yang diperoleh wajib pajak Orang Pribadi atau Badan yang memiliki omzet dibawah 4,8 miliar dikenakan tarif $0,5 \%$. Kebijakan pemerintah ini bertujuan untuk meringankan beban pajak serta menyederhanakan cara perhitungan pajak. Namun kebijakan penurunan tarif pajak final ini menimbulkan pro dan kontra di kalangan masyarakat, khususnya para pelaku bisnis sebagai Wajib Pajak yang berdampak pada tingkat kepatuhan wajib pajak dalam memenuhi kewajiban perpajakannya. Hal ini disebabkan peraturan baru ini mengubah secara signifikan terkait teknik perhitungan maupun tarif pajak yang menjadi beban wajib pajak atas penghasilannya. Meskipun lebih mudah dalam perhitungan, namun secara rasional besarnya pajak yang ditanggung wajib pajak semakin tinggi dan tidak adil, sehingga memicu kebanyakan wajib pajak tidak transparan dalam melakukan pelaporan dan bahkan melakukan penghindaran pajak (tax avoidance).

Kantor Pelayanan Pajak (KPP) Pratama Sekayu merupakan salah satu lembaga pemerintah yang ditugaskan dalam proses pemungutan pajak. KPP Pratama Sekayu telah memberlakukan PP No. 23 Tahun 2018 yang efektif berlaku mulai tanggal 1 Juli 2018 terhadap semua UMKM yang ada di Wilayah kerja mereka, khususnya Kabupaten Musi Banyuasin. KPP Pratama Sekayu juga sangat intens mencari objek pajak UMKM guna mengejar target penerimaan pajak yang telah ditetapkan pemerintah.

Berdasarkan informasi dari bagian Pengolahan Data dan Informasi (PDI) Kantor Pelayanan Pajak (KPP) Pratama Sekayu, diperloleh data seluruh wajib pajak UMKM yang terdaftar dan target penerimaan pajak UMKM selama tiga tahun yaitu Tahun 2018 - 2020 seperti yang disajikan pada Tabel 1.

Tabel 1

KPP PRATAMA Sekayu

Data Wajib Pajak dan Target Penerimaan Pajak UMKM Tahun 2018 - 2020

\begin{tabular}{|c|c|c|}
\hline \hline Tahun Pajak & WP yang Terdaftar & Target Penerimaan Pajak \\
\hline 2018 & 45.902 & 7.860 .553 .000 \\
\hline 2019 & 50.128 & 8.976 .430 .000 \\
\hline 2020 & 52.293 & 9.760 .420 .000 \\
\hline
\end{tabular}

Sumber: Kantor Pelayanan Pajak (KPP) Pratama Sekayu, Tahun 2021 
Berdasarkan data pada tabel 1 diatas dapat dijelaskan bahwa jumlah wajib pajak UMKM yang terdaftar pada Kantor Pelayanan Pajak (KPP) Pratama Sekayu selama Tahun 2018-2020 mengalami peningkatan secara signifikan. Pada Tahun 2018 ke Tahun 2019 meningkat sebesar 4.226 WP UMKM, kemudian pada Tahun 2019 ke Tahun 2020 meningkat sebesar 2.165 WP UMKM. Peningkatan jumlah WP ini dikuti juga dengan peningkatan jumlah target penerimaan pajak UMKM yang ditetapkan oleh KPP Pratama Sekayu. Hal ini menunjukkan bahwa KPP Pratama Sekayu sangat optimis dalam mengejar target penerimaan pajaknya.

Namun muncul pertanyaan, apakah semua wajib pajak yang terdaftar akan membayar pajak semuanya dan apakah target penerimaan pajak yang ditetapkan KPP Pratama akan terealisasi sesuai dengan harapan. Jika sebagian Wajib Pajak UMKM melaksanakan pembayaran pajaknya sesuai ketentuan, tentunya akan mewujudkan realisasi penerimaan pajak yang optimal, sehingga tingkat kepatuhan Wajib Pajak UMKM meningkat dan akan berdampak positif dalam peningkatan penerimaan pajak. Kadang kala fakta dilapangan menunjukkan bahwa peningkatan jumlah wajib pajak tidak dapat menjamin meningkatnya jumlah penerimaan pajak UMKM yang ada di KPP Pratama Sekayu.

Berdasarkan fenomena ini, Penulis tertarik untuk melakukan penelitian dengan judul: Dampak Kepatuhan Wajib Pajak Dalam Meningkatkan Penerimaan Pajak UMKM di KPP Pratama Sekayu.

\subsection{Rumusan Masalah}

Berdasarkan fenomena, maka rumusan masalah dalam penelitian ini adalah: bagaimana dampak kepatuhan wajib pajak UMKM dalam meningkatkan jumlah penerimaan pajak UMKM pada KPP Pratama Sekayu selama Tahun 2018 sampai dengan Tahun 2020 ?

\subsection{Ruang Lingkup Pembahasan}

Penelitian ini hanya akan membahas tentang dampak kepatuhan wajib pajak UMKM dalam meningkatkan penerimaan pajak pada (KPP) Pratama Sekayu Kabupaten Musi Banyuasin.

\subsection{Tujuan dan Manfaat Penelitian}


Berdasarkan rumusan masalah, maka tujuan dari penenelitian ini adalah untuk mengetahui dampak kepatuhan Wajib Pajak UMKM dalam meningkatkan penerimaan pajak Pada KPP Pratama Sekayu Kabupaten Musi Banyuasin. Penelitian ini diharapkan dapat bermanfaat bagi masyarakat pelaku UMKM dalam meningkatkan kepatuhan pajak sehingga dapat berpartisipasi secara maksimal dalam pembangunan melalui pembayaran pajak, serta bagi pemerintah diharapkan dapat menetapkan kebijakan perpajakan yang berpihak kepada para pelaku UMKM sehingga dapat meningkatkan penerimaan pajak di masa yang akan datang.

\section{KAJIAN PUSTAKA}

\subsection{Konsep Usaha Mikro Kecil Menengah (UMKM)}

Undang-Undang Republik Indonesia No. 20 Tahun 2008 Tentang UMKM, menyatakan bahwa Usaha Mikro adalah usaha produktif milik orang perorangan dan/atau badan usaha perorangan yang memenuhi kriteria Usaha Mikro sebagaimana diatur dalam Undang-Undang dan Usaha Kecil adalah usaha ekonomi produktif yang berdiri sendiri, yang dilakukan oleh orang perorangan atau badan usaha yang bukan merupakan anak perusahaan atau bukan cabang perusahaan yang dimiliki, dikuasai, atau menjadi bagian baik langsung maupun tidak langsung dari usaha menengah atau besar yang memenuhi kriteria Usaha Kecil sebagaimana dimaksud dalam Undang-Undang tersebut. Sedangkan Usaha Menengah adalah usaha ekonomi produktif yang berdiri sendiri, yang dilakukan oleh orang perseorangan atau badan usaha yag bukan merupakan anak perusahaan atau cabang perusahaan yang dimiliki, dikuasai, atau menjadi bagian baik langsug maupun tidak langsung dengan Usaha Kecil atau Usaha Besar dengan jumlah kekayaan bersih atau hasil penjualan tahunan sebagaimana diatur dalam Undang-Undang tersebut.

Kriteria UMKM diatur dalam Undang - Undang No. 20 Tahun 2008 Tentang UMKM dan terakhir diatur dalam Peraturan Pemerintah (PP) No. 7 Tahun 2021 Tentang Kemudahan, Perlindungan, dan Pemberdayaan Koperasi dan Usaha MIkro, Kecil, dan Menengah. Dalam Pasal 35 - 36 PP No. 7 Tahun 2021 diatur bahwa pengelompokan UMKM didasarkan atas modal usaha atau hasil penjualan tahunan. Kriteria modal usaha diterapkan untuk pengelompokan UMKM yang baru mau didirikan sesudah PP UMKM. Sedangkan kriteria penjualan tahunan dipakai 
untuk pengelompokan UMKM yang sudah ada sebelum PP ini berlaku. Menurut Pasal 36 ayat (1) PP 7/2021, untuk kepentingan tertentu, kementerian/institusi bisa memakai kriteria omzet, kekayaan bersih, nilai investasi, jumlah tenaga kerja, insentif dan disinsentif, kandungan lokal, dan/atau penggunaan teknologi ramah lingkungan sesuai dengan kriteria tiap-tiap sektor usaha.

Sebelum adanya PP No.7 Tahun 2021, kriteria UMKM 2021 secara khusus sudah diatur pada Undang- Undang No. 20 Tahun 2008 tentang UMKM. Dengan lebih terperinci, kriteria UMKM diatur pada Pasal 6 UU UMKM. Perbedaan kedua peraturan tersebut adalah sebagai berikut:

\begin{tabular}{|c|c|}
\hline \multicolumn{2}{|c|}{ Perbandingan Kriteria UMKM } \\
\hline UU No. 20 Tahun 2008 & PP No.7 Tahun 2021 \\
\hline $\begin{array}{l}\text { UMKM diklasifikasikan menurut kekayaan } \\
\text { bersih atau hasil penjualan tahunan. } \\
\text { Kekayaan bersih adalah jumlah asset } \\
\text { sesudah dikurangi dengan hutang atau } \\
\text { kewajiban. }\end{array}$ & $\begin{array}{l}\text { UMKM diklasifikasikan menurut modal } \\
\text { usaha atau hasil penjualan tahunan. } \\
\text { Modal usaha yakni modal sendiri dan } \\
\text { modal pinjaman untuk melakukan } \\
\text { aktivitas usaha. }\end{array}$ \\
\hline \multicolumn{2}{|c|}{ Kekayaan Bersih/Modal Usaha: } \\
\hline 1. Usaha Mikro: paling banyak Rp. 50 juta & 1. Usaha Mikro: lebih dari Rp. 1 milyar \\
\hline $\begin{array}{l}\text { 2. Usaha Kecil: lebih dari Rp. } 50 \text { juta - } \\
\text { paling banyak Rp. } 500 \text { juta }\end{array}$ & $\begin{array}{l}\text { 2. Usaha Kecil: lebih dari Rp. } 1 \text { milyar } \\
\text { - paling banyak Rp. } 5 \text { milyar. }\end{array}$ \\
\hline $\begin{array}{l}\text { 3. Usaha Menengah: lebih dari Rp. } 500 \text { juta } \\
\text { - paling banyak } 10 \text { milyar }\end{array}$ & $\begin{array}{l}\text { 3. Usaha Menengah: lebih dari Rp. } 5 \\
\text { milyar - paling banyak } 10 \text { milyar. }\end{array}$ \\
\hline Diluar tanah dan bangunan tempat usaha & Diluar tanah dan bangunan tempat usaha \\
\hline \multicolumn{2}{|c|}{ Hasil Penjualan Tahunan } \\
\hline 1. Usaha Mikro: paling banyak Rp.300 juta & 1.Usaha Mikro: paling banyak Rp.2M \\
\hline $\begin{array}{l}\text { 2. Usaha Kecil: lebih dari Rp. } 300 \text { juta - } \\
\text { paling banyak Rp. } 2,5 \text { milyar }\end{array}$ & $\begin{array}{l}\text { 2. Usaha Kecil: lebih dari Rp. } 2 \text { milyar - } \\
\text { paling banyak Rp. } 15 \text { milyar. }\end{array}$ \\
\hline $\begin{array}{l}\text { 3. Usaha Menengah: lebih dari Rp. } 2,5 \\
\text { milyar - paling banyak } 50 \text { milyar. }\end{array}$ & $\begin{array}{l}\text { 3. Usaha Menengah: lebih dari Rp. } 15 \\
\text { milyar - paling banyak } 50 \text { milyar. }\end{array}$ \\
\hline
\end{tabular}

\subsection{Konsep Pajak Usaha Mikro, Kecil dan Menengah (UMKM)}

Pemerintah terakhir mengeluarkan kebijakan yang mengatur pajak atas UMKM pada tanggal 8 Juni 2018, dengan menerbitkan Peraturan Pemerintah Nomor 23 Tahun 2018 Tentang Pajak Penghasilan Atas Penghasilan Dari Usaha Yang Diterima Atau Diperoleh Wajib Pajak Yang Memiliki Peredaran Bruto Tertentu, yang berlaku efektif mulai 1 Juli 2018. Peraturan ini berisi aturan mengenai kemudahan dan insentif kepada pelaku UMKM agar beperan serta dalam kegiatan ekonomi. Bentuk insentif yang dimaksud adalah penurunan tarif Pajak 
Penghasilan $(\mathrm{PPh})$ Final dari $1 \%$ menjadi 0,5\%. Dengan diberikan kebijakan penurunan tarif pajak UMKM ini diharapakan wajib pajak makin mengembangkan usahanya, dan sebagai kontribusi membayar pajak maka penerimaan pajak semakin meningkat.

Objek dari Pajak Penghasilan Final yang dikenakan tarif 0,5\% adalah pajak penghasilan dari usaha yang diterima atau diperoleh wajib pajak yang memiliki predaran bruto tertentu yaitu tidak melebihi 4,8 Miliar dalam satu tahun pajak. Sedangkan penghasilan yang dikecualikan dari objek PP No. 23 Tahun 2018 adalah:

1. Penghasilan yang diterima atau diproleh WP Orang Pribadi dari jasa sehubungan dengan pekerjaan bebas.

2. Penghasilan yang diterima atau diperoleh di luar negri yang pajaknya terutang atau telah dibayar di luar negri.

3. Penghasilan yang telah dikenai Pajak Penghasilan yang bersifat final dengan ketentuanperaturan perundang-undangan perpajakn tersendiri.

4. Penghasilan yang dikeculalikan sebagai objek pajak.

Wajib Pajak yang dikenai PPh Final ini adalah Wajib Pajak Orang Pribadi dan Wajib Pajak Badan berbentuk koperasi, Persekutuan Komaniter, Firma atau Perseroan Terbatas yang menerima atau memperoleh penghasilan dengan predaran bruto tidak melebihi 4,8 Miliar dalam satu tahun pajak. Tidak termasuk Wajib Pajak sebagaimana dimaksud dalam PP No. 23 Tahun 2018 adalah:

1. Wajib Pajak memilih untuk dikenai Pajak Penghasilan berdasarkan tarif Pasal 17 ayat (1) huruf a, pasal 17 ayat (2a), atau Pasal 3IE Undang-Undang Pajak Penghasilan.

2. Wajib Pajak Badan berbentuk Persekutuan atau Firma yang dibentuk oleh beberapa wajib pajak orang pribadi yang memiliki keahlian khusus menyerahkan jasa sejenis dengan jasa sehubungan dengan pekerjaan bebas.

3. Wajib Pajak Badan memperoleh fasilitas Pajak Penghasilan berdasarkan Undang-Undang Pajak Penghasilan Pasal 31A atau PP No. 94 tahun 2010 tentang Penghitungan Penhasilan Kena Pajak dan Pelunasan Pajak Penghasilan dalam tahun berjalan beserta perubhannya. 
4. Wajib Pajak berbentuk Bentuk Usaha Tetap (BUT)

\subsection{Konsep Kepatuhan Pajak}

Kepatuhan perpajakan sangat penting, karena kalau wajib pajak tidak melakukan kewajiban perpajakannya atau tidak patuh menjalankan setiap peraturan perpajakan yang ditetapkan pemerintah, terutama dalam membayar pajak, maka akan berdampak terhadap penurunan penerimaan pajak. Ketidakpatuhan Wajib Pajak juga akan mendorong Wajib Pajak melakukan tindakan- tindakan penggelapan pajak (tax evasion) dan penghindaran pajak, (tax avoidance). Penggelapan pajak (tax evasion) adalah penggelapan secara illegal terhadap objek pajak yang dilakukan perorangan maupun korporasi. Sedangkan penghindaran pajak, (tax avoidance) adalah upaya yang dilakukan untuk menghindari pajak dengan cara memanfaatkan celah pajak (tax loopholes) dalam ketentuan perundang- undangan perpajakan sehingga ditemukan peluang yang dapat dimanfaatkan untuk menghemat pajak atau meminimalisir pajak yang harus dibayar.

Dengan demikian, dapat disimpulkan bahwa penggelapan pajak (tax evasion) merupakan perbuatan curang dalam perhitungan serta pelaporan pajak, sehingga melanggar hukum (illegal) dan merugikan negara. Sedangkan penghindaran pajak, (tax avoidance), adalah perbuatan yang secara hukum diperkenankan yang bertujuan untuk mengefisienkan beban pajak dengan cara melakukan tax planning. Kepatuhan Wajib Pajak merupakan suatu ketaatan untuk melakukan ketentuan- ketentuan atau aturan- aturan perpajakan yang wajib atau diharuskan untuk dilaksanakan. Ini berarti, kepatuhan Wajib Pajak merupakan kepatuhan dalam memenuhi kewajiban perpajakannya. Kewajiban Wajib Pajak seperti diatur dalam Undang- Undang KUP adalah: mendaftarkan diri untuk mendapatkan NPWP, membayar pajak, melaporkan pajak, memungut/ memotong pajak, menyelenggarakan pembukuan dan memberikan data/ informasi yang diperlukan pada saat dilaksanakan pemeriksaan oleh petugas pajak.

Kepatuhan wajib pajak mencakup kepatuhan mencatat atau membukukan transaksi usaha, kepatuhan melaporkan kegiatan usaha sesuai peraturan yang 
berlaku, serta kepatuhan terhadap semua aturan perpajakan lainnya. Di antara ketiga jenis kepatuhan tersebut, yang paling mudah diamati adalah kepatuhan melaporkan kegiatan usaha, karena seluruh wajib pajak berkewajiban menyampaikan laporan kegiatan usahanya setiap bulan dan/atau setiap tahun dalam bentuk menyampaikan Surat Pemberitahuan (SPT) dalam setiap masa atau Tahunannya. ( Saeroji, 2017).

\subsection{Faktor- Faktor yang Mempengaruhi Penerimaan Pajak}

Rahayu (2017: 27-29), menyatakan bahwa, faktor-faktor yang mempengaruhi penerimaan pajak adalah sebagai berikut:

1. Kejelasan, kepastian dan kesederhanaan peraturan perundang-undangan perpajakan, Undang-undang yang jelas, sederhana dan muda dimengerti akan memberi penjelasan yang serupa bagi wajib pajak dan fiskus dan tidak menimbulkan kesalahan interprestasi.

2. Kebijakan pemerintah dalam menerapkan Undang-ndang perpajakan, merupakan suatu cara atau alat pemerintah di bidang perpajakan yang memiliki suatu sasaran tertentu atau alat untuk mencapai suatu tujuan tertentu di bidang sosial dan ekonomi. Kebijakan dalam hal ini ialah denganadanya keputusan menteri keuangan meupun suarta edaran dari Direktorat Jendral pajak, mengenai hal-hal tertentu dalam hal perpajakan yang tidak dijelaskan secara rinci.

3. Sistem administrasi perpajakan diharapkan tidak rumit, tetapi ditekankan pada kesederhanaan prosedur.

4. Salah satu langkah penting yang harus dilakukan pemerintah sebagai wujud nyata kepedulian pada pentingnya kualitas pelayanan adalah memberikan pelayanan prima kepada wajib pajak dalam mengoptimalkan penerimaan negara.

5. Kesadaran dan pemahaman warga negara, rasa nasionalisme tinggi, kepedulian kepada bangsa dan negara serta tingkat pengetahuan perpajakan masyarakat yang memadai, maka secara umum akan makin mudah bagi Wajib Pajak untuk patuh kepada peraturan perpajakan.

6. Kualitas petugas pajak (intelektual, keterampilan, intergritas, moral tinggi), sangat menentukan efektivitas Undang-Undang dan peraturan perpajakan. Petugas pajak memiliki reputasi yang baik sepanjang yang menyangkut 
kecakapan teknis, efisien dan efektif dalam hal kecepatan, tepat dan keputusan yang adil. Petugas pajak harus kompeten pada bagiannya, dapat menggali obyekobyek pajak yang menurut Undan-Undang harus dikenakan pajak, tidak begitu saja memperayai keterangan dan laporan keungan yang dilaporkan wajib pajak. All in all a good job yang berarti aparat pajak juga harus benar-benar mampu dan ahli di bidangnya masing-masing.

\subsection{Kerangka Pemikiran}

Kerangka pemikiran dalam penelitian ini disajikan pada gambar 1. Dari gambar 1 dapat dijelaskan bahwa dalam penelitian ini akan dianalisis tentang kepatuhan wajib pajak UMKM dalam mematuh peraturan PP No. 23 Tahun 2018 dan bagaimana dampaknya dalam meningkatkan penerimaan pajak UMKM.

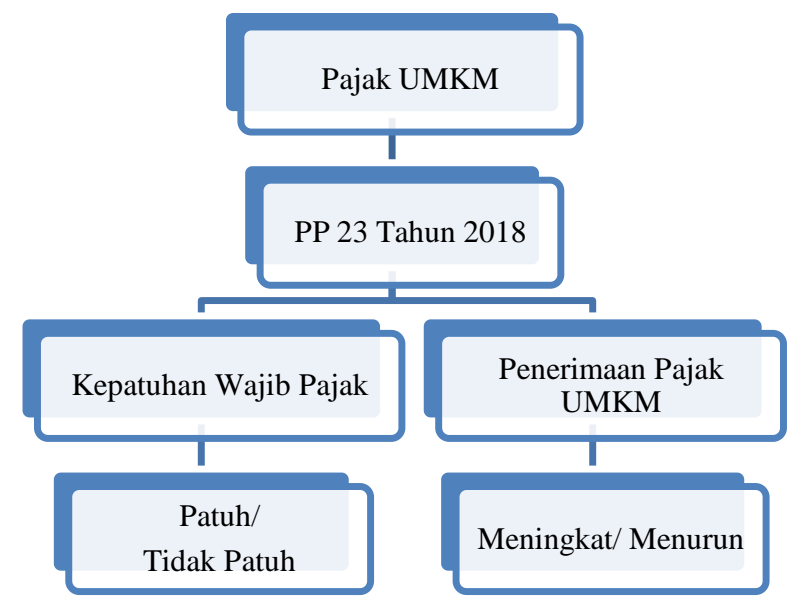

Gambar 1

Kerangka Pemikiran

\section{METODOLOGI PENELITIAN}

Penelitian ini menggunakan metode deskriptif, seperti yang dijelaskan oleh Sugiyono (2018: 86), bahwa penelitian deskriptif adalah penelitian yang dilakukan untuk mengetahui nilai variabel mandiri baik satu variabel atau lebih (independen) tanpa membuat perbandingan atau menghubungkan dengan variabel lain.

Penelitian ini dilakukan di Kantor Pelayanan Pajak (KPP) Pratama Sekayu. Data penelitian yang digunakan adalah data sekunder berupa data jumlah wajib pajak UMKM yang terdaftar, membayar dan tidak membayar serta target dan realisasi penerimaan pajak UMKM di Kantor Pelayanan Pajak (KPP) Pratama 
Sekayu Kabupaten Musi Banyuasin selama Tahun 2018 - 2020. Data diperoleh dengan menggunakan teknik dokumentasi dan wawancara dengan Bagian Pengolahan Data dan Informasi KPP Pratama Sekayu. Dokumentasi yaitu pengumpulan data yang diperoleh melalui dokumen-dokumen yang ada pada instansi yang terkait dengan mengumpulkan data sekunder melalui catatan-catatan dan dokumen-dokumen yang ada pada instansi yang diteliti yaitu Kantor Pelayanan Pajak (KPP) Pratama Sekayu.

Analisis data menggunakan teknik analisis kuantitatif, yaitu mengalisis data wajib pajak UMKM yang terdaftar, membayar, tidak membayar serta data target dan realisasi penerimaan pajak UMKM dengan terlebih dahulu membuat perhitungan, selanjutnya menginterpretasi serta mendeskripsikan data hasil perhitungan guna menarik kesimpulan hasil penelitian.

\section{PEMBAHASAN}

Berdasarkan data yang diperoleh dari KPP Pratama Sekayu, maka Penulis akan melakukan proses pengolahan dan analisis data.

\subsection{Analisis Kepatuhan Wajib Pajak UMKM}

Kepatuhan Wajib Pajak akan dinilai dari pelaksanaan kewajiban mendaftarkan diri menjadi Wajib Pajak UMKM, dan kewajiban membayar pajak yang didasarkan pada data jumlah wajib pajak yang terdaftar dan membayar pajak seperti yang disajikan pada Tabel 3.

Tabel 2

KPP PRATAMA Sekayu

Data Wajib Pajak UMKM

Tahun 2018 - 2020

\begin{tabular}{|c|c|c||c|c|c||}
\hline $\begin{array}{c}\text { Tahun } \\
\text { Pajak }\end{array}$ & $\begin{array}{c}\text { WP } \\
\text { Terdaftar }\end{array}$ & $\begin{array}{c}\text { WP } \\
\text { Membayar }\end{array}$ & $\begin{array}{c}\text { Pesentase } \\
\text { WP Yang } \\
\text { Membayar } \\
\text { Pajak }\end{array}$ & $\begin{array}{c}\text { WP Tidak } \\
\text { Membayar }\end{array}$ & $\begin{array}{c}\text { Pesentase WP } \\
\text { Yang Tidak } \\
\text { Membayar } \\
\text { Pajak }\end{array}$ \\
\hline 2018 & 45.902 & 11.811 & $25,73 \%$ & 34.091 & $74,27 \%$ \\
\hline 2019 & 50.128 & 15.276 & $30,47 \%$ & 34.852 & $69,53 \%$ \\
\hline 2020 & 52.293 & 18.502 & $35,38 \%$ & 33.791 & $64,62 \%$ \\
\hline
\end{tabular}

Sumber: Kantor Pelayanan Pajak (KPP) Pratama Sekayu, Tahun 2021

Berdasarkan data Tabel 3, dapat dijelaskan bahwa jumlah wajib pajak

UMKM yang terdaftar sangat besar dan mengalami peningkatan yang cukup 
signifikan dari Tahun 2018 ke Tahun 2019 meningkat sebanyak 4.226 Wajib Pajak. Selanjutnya Tahun 2020 meningkat lagi sebesar 2.165 Wajib Pajak. Ini menunjukkan bahwa selama kurun waktu 2 tahun Wajib Pajak UMKM di KPP Pratama Sekayu meningkat sebesar 6.391 Wajib Pajak.

Untuk lebih jelas kepatuhan Wajib Pajak UMKM dapat diilustrasikan ke dalam bentuk grafik seperti yang disajikan pada grafik 1. Dari gambar pada grafik 1, terlihat bahwa jumlah wajib pajak yang mendaftarkan diri setiap tahunnya meningkat terus. Pada Tahun 2018 sebanyak 45.902 Wajib Pajak,. Sedangkan Tahun 2019 jumlah Wajib Pajak yang terdaftar sebanyak 50.128 Selanjutnya pada Tahun 2020 jumlah Wajib Pajak yang terdaftar sebanyak 52.293 Wajib Pajak.

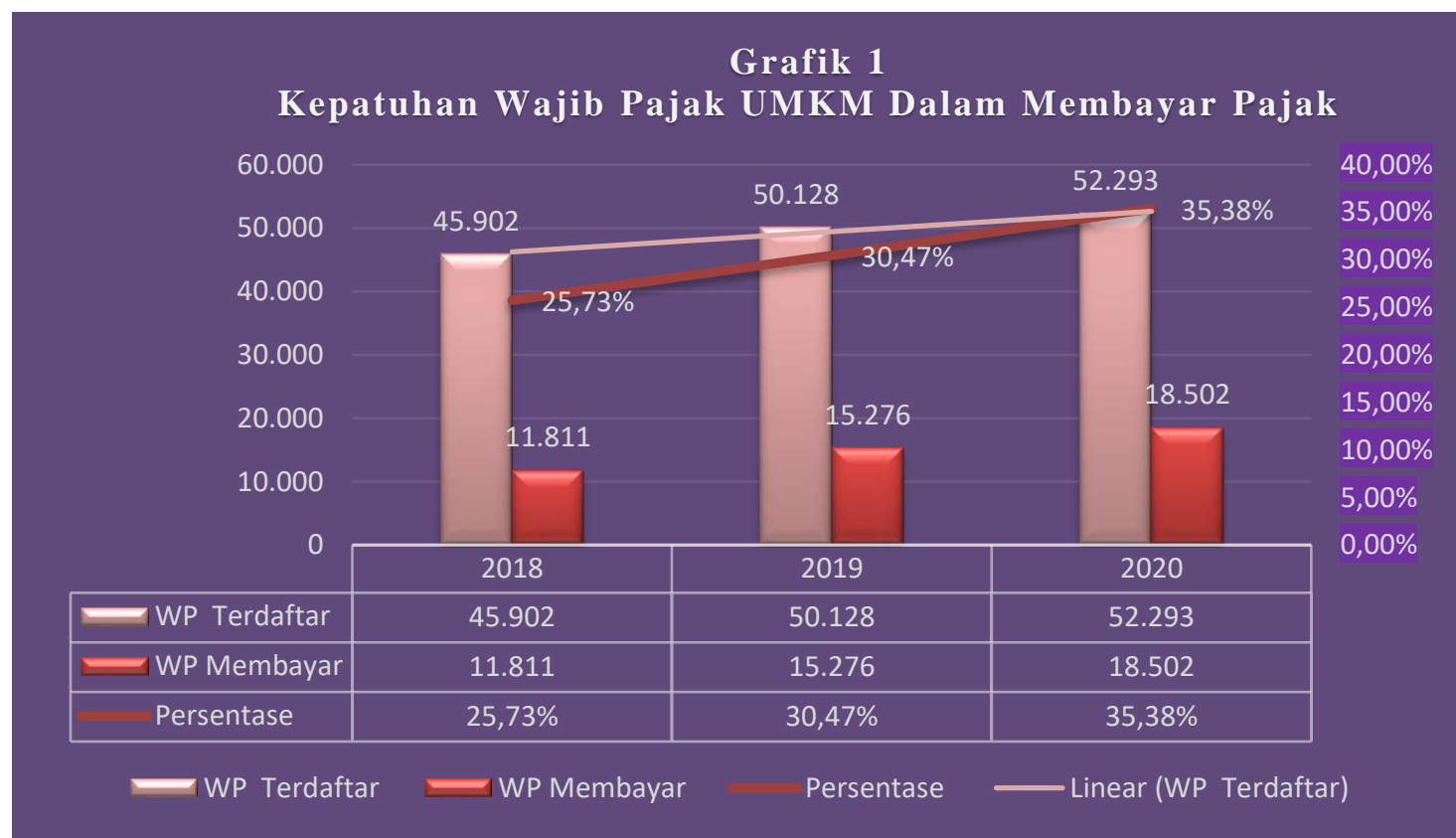

Dengan demikian dapat disimpulkan bahwa tingkat kepatuhan Wajib Pajak dalam mendaftarkan diri sangat tinggi selama Tahun 2018 - 2020. Hal ini disebabkan karena semua Wajib Pajak UMKM diWajibkan memiliki NPWP dan NPWP merupakan salah satu syarat untuk mendapat berbagai bantuan baik itu dana bergulir maupun fasilitas sarana dan prasarana dari pemerintah khususnya Pemerintah Daerah Kabupaten Musi Banyuasin. Selain itu pemerintah juga menawarkan insentif pajak bagi Wajib Pajak UMKM, sehingga pelaku UMKM termotivasi untuk mendaftarkan diri untuk mendapatkan NPWP. Namun Kepatuhan dalam mendaftarkan diri menjadi Wajib Pajak UMKM tidak 
memberikan respon positif dalam membayar pajak, karena terlihat dari grafik 1, bahwa. Pada Tahun 2018 yang membayar hanya sebanyak 11.811 Wajib Pajak atau 25, 73\%. dan Tahun 2019 yang membayar hanya sejumlah 15.276 Wajib Pajak atau sebesar 30,47\%, serta Tahun 2020 yang membayar hanya sejumlah 18.502 Wajib Pajak atau 35,38\%. Dengan demikian selama tiga tahun rata- rata tingkat kepatuhan Wajib Pajak UMKM dalam membayar pajak tidak sampai $40 \%$ yaitu hanya sebesar 30,53\%. Hal ini menunjukkan bahwa tingkat kepatuhan Wajib Pajak yang membayar pajak masih sangat rendah. Kondisi ini dipicu oleh rasa ketidakadilan bagi Wajib Pajak karena dalam pengenaan pajak atas WP UMKM diberlakukan tarif final $0,5 \%$ dari omzet yang mereka terima. Meskipun tarifnya rendah, namun karena penerapannya dihitung dari tarif $0,5 \%$ dikali dengan omzet penjualan, maka berapapun jumlah hasil penjualan mereka tetap akan dikenakan pajak. Padahal fakta dilapangan terkadang usaha mereka sedang mengalami kerugian. Perlakuan yang dirasa oleh WP UMKM tidak adil adalah dalam keadaan rugi mereka tetap dikenakan pajak karen pengenaan pajak tidak didasarkan pada laba usaha.

\subsection{Analisis Atas Penerimaan Pajak UMKM}

Data target dan realisasi penerimaan pajak UMKM disajikan pada Tabel 4. Berdasarkan data pada Tabel 4 dapat dijelaskan bahwa jumlah target penerimaan pajak UMKM Tahun 2018 sebesar Rp. 7.860.553.000, dan mengalami peningkatan pada Tahun 2019 sebesar Rp. 1.115.877.000 menjadi Rp. 8.976.430.000. Pada Tahun 2020 meningkat juga sebesar Rp. 783.990.000 menjadi Rp. 9.760.420.000. Dari jumlah target penerimaan yang ditetapkan oleh KPP Pratama Sekayu setiap tahunnya, terlihat bahwa dalam penetapan target tidak didasarkan pada realisasi penerimaan pajak tahun sebelumnya dan tanpa mempertimbangkan potensi Wajib Pajak dalam membayar pajak. Fakta yang terjadi bahwa target penerimaan meningkat setiap tahunnya, sedangkan realisasi cenderung mengalami penurunan.

Tabel 3

KPP PRATAMA Sekayu

Data Target dan Realisasi Penerimaan Pajak UMKM

Tahun $2018-2020$

\begin{tabular}{|l|c|c|c|}
\hline $\begin{array}{l}\text { Tahun } \\
\text { Pajak }\end{array}$ & Target & Realisasi & $\begin{array}{c}\text { Pesentase } \\
\text { Pealisasi Pajak }\end{array}$ \\
\hline
\end{tabular}




\begin{tabular}{|l|l|l|l|}
\hline 2018 & 7.860 .553 .000 & 6.095 .784 .302 & $77,55 \%$ \\
\hline 2019 & 8.976 .430 .000 & 6.146 .734 .858 & $68,48 \%$ \\
\hline 2020 & 9.760 .420 .000 & 4.438 .544 .305 & $45,73 \%$ \\
\hline
\end{tabular}

Sumber: Kantor Pelayanan Pajak (KPP) Pratama Sekayu, Tahun 2021

Untuk melihat secara riil perkembangan target dan realisasi penerimaan pajak disajikan pada grafik 2 .

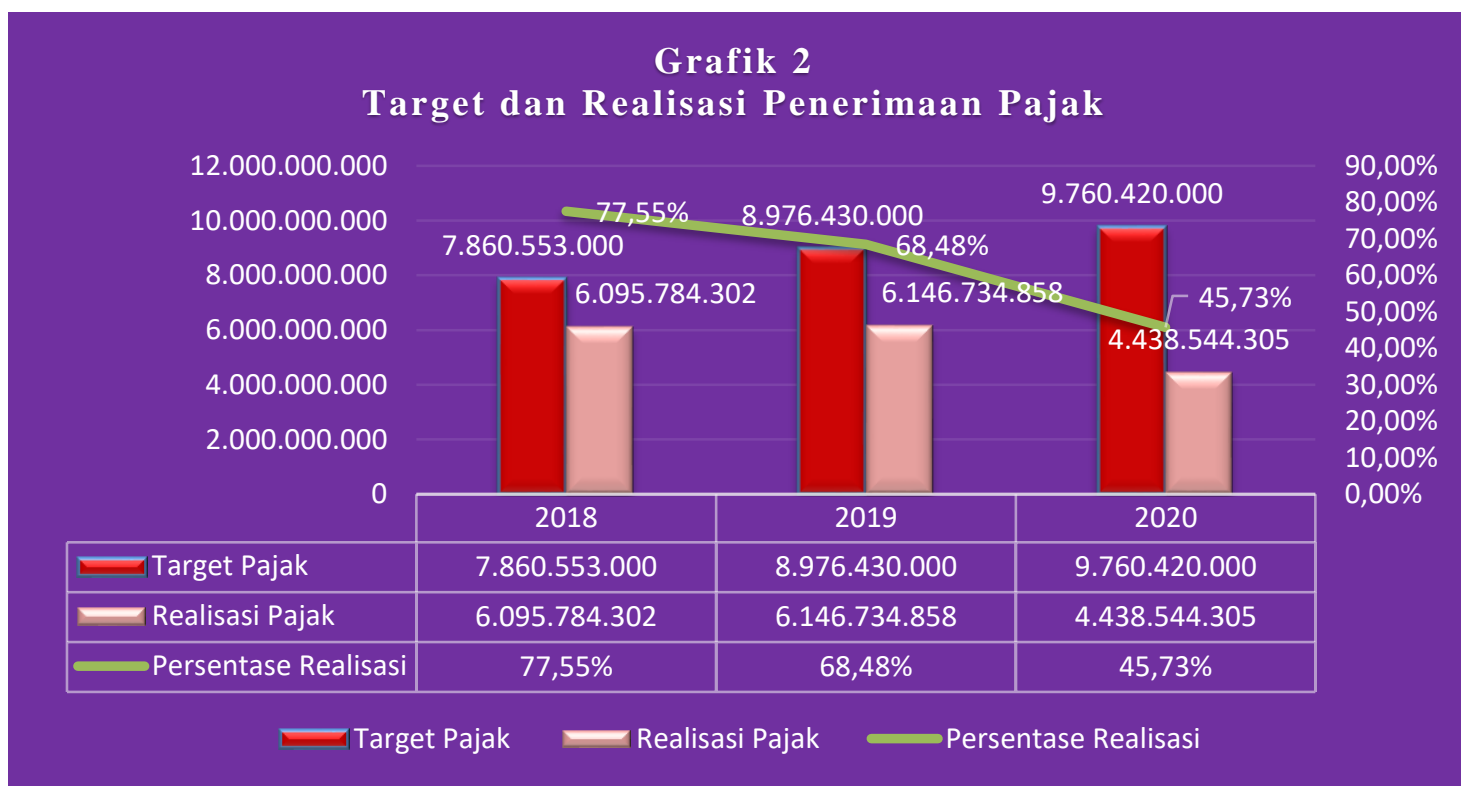

Dari Grafik 2, dapat dijelaskan bahwa realisasi penerimaan pajak pada Tahun 2018 sebesar Rp. 6.095.784.302 atau sebesar 77,55\%, dan pada Tahun 2019 meningkat sebesar Rp. 50.950.556 menjadi Rp. 6.146.734.858 atau hanya mencapai $68,48 \%$. Angka ini menunjukkan bahwa secara persentase realisasi penerimaan pajak UMKM mengalami penurunan sebesar lebih kurang 9\%. Selanjutnya pada Tahun 2020 realisasi penerimaan pajak UMKM hanya sebesar Rp. 4.438.544.305 atau sebesar $45,73 \%$ saja. Tentu saja fakta ini menunjukkan bahwa realisasi penerimaan pajak mengalami penurunan yang sangat signifikan dari tahun sebelumnya yaitu sebesar $22,75 \%$. Penurunan realisasi penerimaan pajak pada Tahun 2020 dipicu oleh pandemi Covid-19 yang menyebabkan banyak UMKM yang tidak produktif dan usahanya macet total, sehingga sebagian besar UMKM gulung tikar. 
Dengan demikian dapat disimpulkan bahwa realisasi penerimaan pajak UMKM selama Tahun 2018 -2020, hanya mencapai 63,92\%. Realisasi penerimaan pajak yang rendah ini disebabkan oleh masih rendahnya kepatuhan Wajib Pajak dalam membayar pajak dan ditambah dengan pandemic Covid-19 yang dialami seluruh dunia.

\subsection{Analisis Dampak Kepatuhan Wajib Pajak UMKM Dalam Meningkatkan Penerimaan Pajak UMKM}

Berdasarkan penjelasan pada pembahasan kepatuhan wajib pajak UMKM dan penerimaan pajak UMKM, maka akan dianalisis dampak kepatuhan Wajib Pajak UMKM dalam meningkatkan penerimaan pajak UMKM. Berikut ini akan disajikan data sebagai dasar analisisnya, seperti pada Tabel 4.

Tabel 4

KPP PRATAMA Sekayu

Data Kepatuhan Membayar Pajak dan Realisasi Penerimaan Pajak UMKM Tahun $2018-2020$

\begin{tabular}{|c|c|c|c|c|}
\hline $\begin{array}{l}\text { Tahun } \\
\text { Pajak }\end{array}$ & $\begin{array}{l}\text { Wajib } \\
\text { Pajak } \\
\text { Patuh }\end{array}$ & $\begin{array}{c}\text { Persentase } \\
\text { Kepatuhan }\end{array}$ & $\begin{array}{c}\text { Realisasi } \\
\text { Penerimaan pajak }\end{array}$ & $\begin{array}{c}\text { Pesentase } \\
\text { Realisasi Pajak }\end{array}$ \\
\hline 2018 & 11.811 & $25,73 \%$ & 6.095 .784 .302 & $77,55 \%$ \\
\hline 2019 & 15.276 & $30,47 \%$ & 6.146 .734 .858 & $68,48 \%$ \\
\hline 2020 & 18.502 & $35,38 \%$ & 4.438 .544 .305 & $45,73 \%$ \\
\hline \multicolumn{2}{|r|}{ Rata-rata } & $30,53 \%$ & & $63,92 \%$ \\
\hline
\end{tabular}

Sumber: Kantor Pelayanan Pajak (KPP) Pratama Sekayu, Tahun 2021

Dari Tabel 4 diatas diilustrasikan dalam bentuk grafik seperti disajikan pada Grafik 3. Berdasarkan Tabel 4 dan ilustrasi pada Grafik 3, dapat dijelaskan bahwa persentase kepatuhan Wajib Pajak dalam membayar pajak selama Tahun 2018 2020 mengalami peningkatan secara terus- menerus. Pada Tahun 2018 sebesar 25,73\% dan pada Tahun 2019 meningkat sebesar 4,74\% menjadi 30,47\%. Sedangkan Tahun 2019 sebesar 30,47\% meningkat sebesar 4,91\% menjadi 35,38\% pada Tahun 2020. Namun tren peningkatan persentase kepatuhan Wajib Pajak dalam membayar pajak kontradiksi dengan realisasi penerimaan pajak karena persentase realisasi penerimaan pajak selama Tahun 2018 - 2020 mengalami penurunan yang cukup signifikan. Pada Tahun 2018 sebesar 77,55\% mengalami 
penurunan pada Tahun 2019 sebesar 9,07\% menjadi 68,48\%. Sedangkan pada Tahun 2020 sebesar 45,73\%, artinya mengalami penurunan sebesar 22,75\%. Ratarata penurunan sebesar $15,91 \%$.

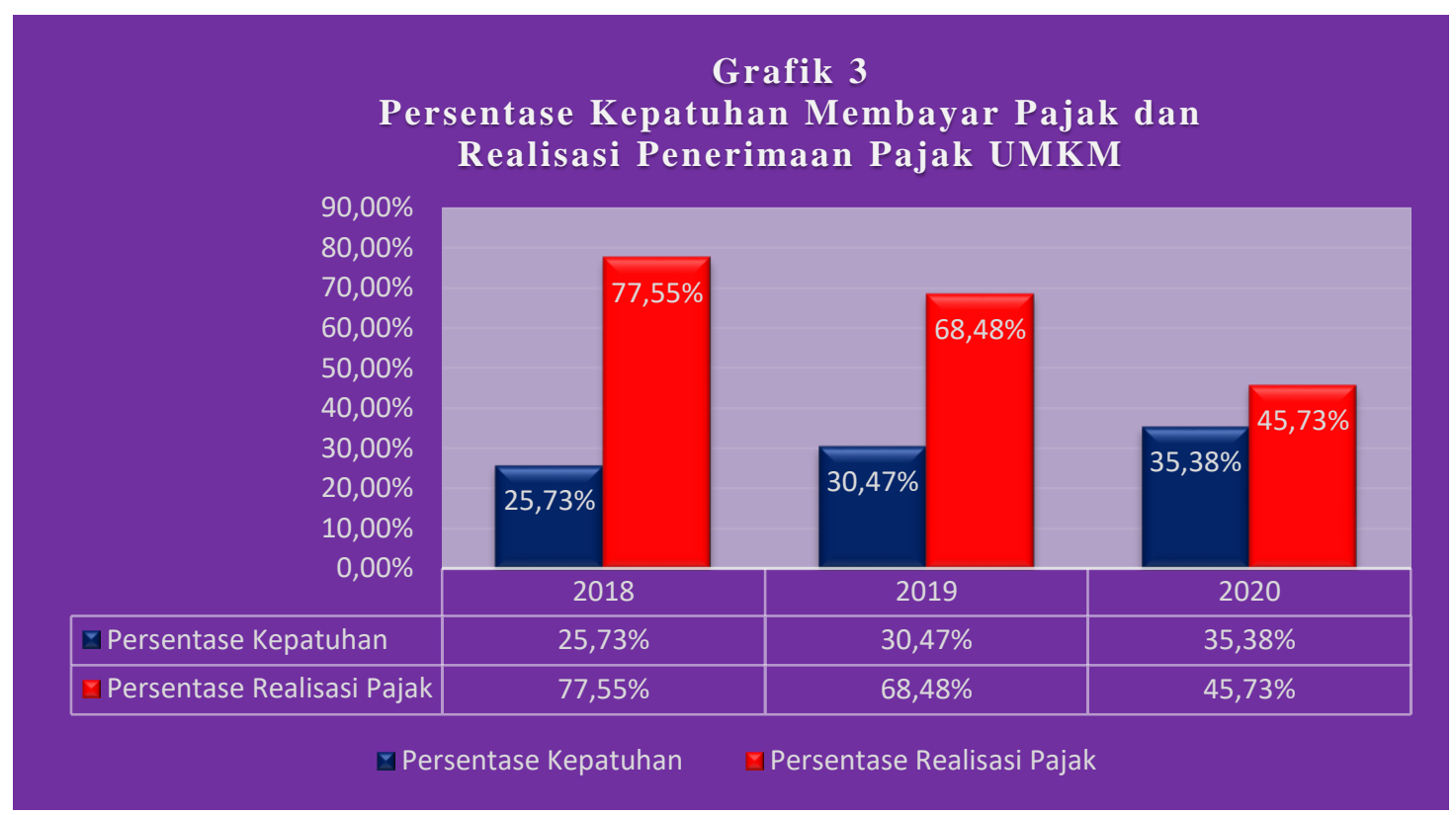

Dengan demikian dapat disimpulkan bahwa peningkatan kepatuhan Wajib

Pajak dalam membayar pajak belum tentu dapat meningkatkan jumlah penerimaan pajak. Hal ini disebabkan karena jumlah Wajib Pajak yang membayar adalah Wajib Pajak yang jumlah omzet pajaknya kecil, namun jumlah Wajib Pajaknya besar sehingga meskipun mereka patuh tetap saja jumlah realisasi penerimaan pajaknya kecil. Jadi Wajib Pajak yang jumlah omzetnya besar cenderung melakukan penggelapan pajak (tax evasion) dengan cara tidak melaporkan data yang sebenarnya bahkan mangkir dari membayar pajak.

Rendahnya kepatuhan wajib pajak disebabkan oleh beberapa faktor, antara lain masyarakat merasa tidak puas terhadap pelayanan publik yang mereka terima, pembangunan infrastruktur yang tidak dapat memenuhi kebutuhan masyarakat, dan terjadinya penggelapan (kasus korupsi) uang pajak yang dilakukan oleh pejabat pajak maupun pejabat negara lainnya, sehingga menciptakan ketidakpercayaan public terhadap penyelenggara pemerintahan. Berdasarkan hasil wawancara yang dilakukan, salah satu penyebabnya adalah masyarakat kurang merasakan manfaat dari hasil pajak yang telah mereka bayar, contohnya masih banyaknya jalan yang rusak dan sarana publik yang tidak memadai serta kasus korupsi yang semakin 
meningkat baik pusat ataupun daerah serta pelayanan publik yang belum memuaskan masyarakat.

\section{SIMPULAN DAN SARAN}

\subsection{Simpulan}

Berdasarkan hasil analisis dan pembahasan mengenai dampak kepatuhan Wajib Pajak UMKM dalam meningkatkan Penerimaan Pajak UMKM pada KPP Pratama Sekayu, maka dapat disimpulkan bahwa:

1. Kepatuhan Wajib Pajak UMKM yang terdaftar di KPP Pratama Sekayu selama Tahun 2018 - 2020 mengalami peningkatan, namun dikategorikan masih sangat rendah dengan rata- rata kepatuhan yang dicapai hanya 30,53\%. Hal ini disebabkan karena jumlah Wajib Pajak yang membayar adalah Wajib Pajak yang jumlah omzet pajaknya kecil, namun jumlah Wajib Pajaknya besar sehingga meskipun mereka patuh tetap saja jumlah realisasi penerimaan pajaknya kecil.

2. Kepatuhan Wajib Pajak UMKM yang terdaftar di KPP Pratama Sekayu selama Tahun 2018 - 2020, tidak memberikan dampak positif dalam meningkatkan penerimaan pajak UMKM karena meskipun persentase kepatuhan Wajib Pajak dalam membayar pajak mengalami peningkatan, namun penerimaan pajak UMKM terus mengalami penurunan dengan rata- rata 15,91\%. Realisasi penerimaan pajak UMKM belum optimal, dengan rata- rata tingkat pencapaian penerimaan pajak hanya 63,92\%. Penurunan yang sangat signifikan terjadi di Tahun 2020 yaitu sebesar 22,75\%, kondisi ini sebagai dampak pandemi Covid19 sehingga banyak UMKM yang terpaksa gulung tikar karena operasionalnya mereka tidak berjalan.

\subsection{Saran}

Dalam rangka meningkatkan kesadaran Wajib Pajak guna menyikapi penyebab rendahnya kepatuhan pajak dan untuk meningkatkan kepatuhan wajib pajak dalam memenuhi kewajiban pajaknya terutama dalam melaporkan pajaknya sehingga dapat diperoleh data pajak yang valid, maka pemerintah harus melakukan beberapa hal berikut, antara lain: 
1. Meningkatkan pelayanan publik secara profesional, mengelola dan memanfaatkan uang hasil pembayaran pajak secara merata, adil dan transparan,

2. Membuat peraturan perpajakan yang memberikan pelayanan serta kemudahan kepada Wajib Pajak baik dalam administrasi maupun dalam proses pembayaran pajak,

3. Memberikan sanksi hukum yang lebih tegas kepada wajib pajak yang tidak patuh sehingga menunjukkan sikap perlakuan hukum yang adil kepada semua Wajib Pajak apabila melakukan pelanggaran pajak.

4. Meningkatkan program sosialisasi dan pelatihan kepada Wajib Pajak terutama tentang mekanisme perhitungan, pembayaran dan pelaporan pajak baik secara langsung maupun online.

5. Merancang dan membuat sistem yang lebih sederhana dan memberikan kemudahan kepada Wajib Pajak dalam menyampaikan Surat Pemberitahuan (SPT) Tahunan Pajak Penghasilan bagi Wajib Pajak Orang Pribadi maupun Badan melalui SPT secara elektronik atau biasa dikenal dengan $e$-filing / $e$-SPT sehingga lapor pajak lebih mudah, cepat serta efisien tidak perlu waktu yang lama untuk melaporkan pajaknya.

\section{DAFTAR PUSTAKA}

Pemerintah Republik Indonesia. 2008. Undang-Undang Nomor 20 Tahun 2008 Tentang Usaha Mikro, Kecil, dan Menegah. Jakarta: Sekretariat Negara.

Pemerintah Republik Indonesia. 2009. Undang-Undang Nomor 16 Tahun 2009 Tentang Ketentuan Umum dan Tata Cara Perpajakan. Jakarta: Sekretariat Negara.

Pemerintah Republik Indonesia. 2018. Peraturan Pemerintah Nomor 23 Tahun 2018 Tentang Pajak Peghasilan dari Usaha Yang Diterima atau Diperoleh Wajib Pajak Yang Memiliki Predaran Bruto Tertentu. Jakarta: Sekretariat Negara.

Pemerintah Republik Indonesia. 2021. Peraturan Pemerintah (PP) Nomor 7 Tahun 2021 Tentang Kemudahan, Perlindungan, dan Pemberdayaan Koperasi dan Usaha MIkro, Kecil, dan Menengah. Jakarta: Sekretariat Negara.

Rahayu, Siti Kurnia. 2017. Perpajakan Konsep dan Aspek Formal. Yogyakarta: Graha Ilmu. 
Jurnal Ilmiah Akuntansi Rahmaniyah (JIAR)

Vol. 5 No. 1, Desember 2021, 56 - 73

Aryani

Saeroji, Oji. 2017. Menakar Kadar Kepatuhan Wajib Pajak. https://www.pajak.go.id/id/artikel/menakar-kadar-kepatuhan-wajib-pajak. Diakses: Rabu, 26 Januari 2022.

Sugiyono. 2018. Metode Penelitian Kuantitatif, Kualitatif, dan R\&D. Bandung: Alfabeta. 